\title{
21. PETROLOGY AND CHEMICAL COMPOSITION OF BASALTIC ROCKS RECOVERED ON LEG 32, DEEP SEA DRILLING PROJECT
}

\author{
Monte Marshall, U.S. Geological Survey, Menlo Park, California
}

\begin{abstract}
A variety of altered to highly altered basaltic rocks was cored at four localities during Leg 32. The basaltic rocks recovered at Sites 303, 304, and 307, all in presumed Mesozoic ocean floor, retain enough petrographic and chemical characteristics to permit classification as ocean-ridge-type tholeitic basalts. The basaltic material recovered at Site 313, on the other hand, proved to be alkalic in character, and probably originally was a basanite or nephelenite. Flow units were difficult to delimit because of poor core recovery, but at least two and perhaps as many as seven units were penetrated at Site 303. The 13 meters of tholeiites penetrated at Site 304 apparently consisted of a single flow unit. At Site 307 six basalt units were intercalated with three hyaloclastites. At Site 313, two flow units may have been penetrated. A study of the progressive chemical changes of these basaltic rocks during alteration suggests that $\mathrm{TiO}_{2}$, $\mathrm{Co}, \mathrm{Cr}, \mathrm{Sc}$, and $\mathrm{Zr}$ contents of the rocks remain relatively unchanged and should serve to help identify the petrologic character of altered volcanic rocks on the ocean floors.
\end{abstract}

\section{INTRODUCTION}

On Leg 32, basalt was drilled at four holes-303A, 304, 307, and 313. In Hole 303A, 9 meters of basalt were drilled, 2.5 meters recovered; at Site 304, 13 meters were drilled, 8.1 meters recovered; at Site 307, 9 meters of basalt and hyaloclastite were drilled, 4.1 meters recovered; and at Site 313,12 meters of basalt were drilled, 6.2 meters recovered. No contacts between basalt and overlying sediments were recovered. As a group, the basalts were moderately to highly altered. Petrography and chemical composition of the freshest samples at Sites 303, 304, and 307 indicate that they are tholeiites of the oceanic type. The basalt cored at Site 313, on the other hand, is clearly alkalic. The large amounts of nepheline in the norms of the rocks cored at this site suggest the fresh basalts were basanites or nephelinites, but no trace remains of the modal nepheline that would lead to more precise nomenclature of these rocks.

Because of the extensive alteration, an effort was made to sample and chemically analyze the freshest and the most altered basaltic rock at each site, and a study of the effect of alteration on the concentration of major and minor elements was made.

\section{CORE DESCRIPTIONS}

Basaltic rocks recovered at Holes 303A, 304, and 307 all proved to be fine grained, aphyric, and partially altered. All contain small, sparse vesicles $(<1 \mathrm{~mm}$ in diameter) usually filled with calcite and clay minerals subsequently identified as celadonite and montmorillonite. The fairly homogeneous appearance of the basalts is broken by numerous fractures. The average fracture spacing is only a few centimeters, and they are usually filled with calcite and clay minerals, subsequent- ly also identified as celadonite and montmorillonite. Of special interest are the three veins of calcite and chalcedony, $2 \mathrm{~cm}$ thick, that cut the basalt at Site 304, because the central vein contains pyritized fecal pellets (Favreina).

In contrast, the fine-grained, aphyric basaltic rock from Site 313 contained both small vesicles filled with calcite and zeolites and vugs up to $2 \mathrm{~cm}$ in diameter lined or filled to varying degrees with calcite, sugary rhombs of ankerite, and cream-colored to clear, drusy masses of phillipsite.

Although no glassy crusts were found between the basaltic rocks at Site 303, there are indications of multiple cooling units. In addition to several alternating zones of darker, more finely crystalline and lighter, less finely crystalline basalt, varioles were observed at the end of a core segment $22 \mathrm{~cm}$ below the top of the basalt section there. Variolitic texture is characteristic of the quench crystallization immediately adjacent to glassy crusts. Thus, this basaltic section consists of two and, in light of the variations in granularity, perhaps as many as seven cooling units.

The 13 meters of basalt at Site 304 has no obvious textural variations and apparently forms one cooling unit.

The usual glassy crusts which delineate flow margins were recovered only at Site 307 . The 4.1 meters of volcanic rocks recovered at this site consist of six basalt units (pillows?) interbedded with three layers of hyaloclastite. The basalt units are $15-75 \mathrm{~cm}$ thick and have $1 / 2$ to 2 -cm-thick glassy crusts. The breccia units, or hyaloclastites, consist of small $(0.1-1 \mathrm{~cm})$ fragments of glass and larger fragments $(1-4 \mathrm{~cm})$ of glassy basalt cemented by calcite and ankerite. Waxy, green celadonite and montmorillonite replace almost all the original black vitreous glass in the hyaloclastite and at the flow margins. 
The textural evidence for multiple flows at Site 313 consists only of two zones, about a meter below the top of the basaltic section, where the basalt is slightly finer grained and has a brownish discoloration. Slight mineralogic differences of the upper meter, as shown by a lack of K-feldspar, also suggests it may be a separate flow.

\section{PETROGRAPHY}

Thin sections of the basaltic rocks showed them all to be altered to the extent that refined nomenclature based on the presence or absence of primary $\mathrm{K}$-feldspar and nepheline (Macdonald and Katsura, 1964) could not be applied. Detailed petrographic descriptions of selected samples are given in Table 1. No olivine, nor altered relicts to suggest its former presence were found in any of the thin sections examined. The spotty presence of plagioclase microphenocrysts and glomeroporphyritic clots of plagioclase and pyroxene in the fresher basaltic units at Sites 303, 304, and 307 are suggestive of those found in oceanic tholeiites. The presence of titanaugite,

TABLE 1

Thin Section Description of Analyzed Samples

\begin{tabular}{|c|c|c|c|}
\hline $\begin{array}{c}\text { Sample } \\
\text { (Interval in } \mathrm{cm} \text { ) }\end{array}$ & Code & $\begin{array}{l}\text { Increasing } \\
\text { Alteration }\end{array}$ & Thin Section Description \\
\hline
\end{tabular}

\begin{tabular}{llll}
\hline Hole 303A & A & $\begin{array}{l}\text { Intersertal texture of plagioclase laths, pyroxene, abundant opaque } \\
\text { grains; much of the pyroxene and groundmass altered to green mont- } \\
\text { morillonite }\end{array}$ \\
$10-1,120$ & $303 \mathrm{~A}-\mathrm{A}^{\mathrm{a}}, \mathrm{A}^{\mathrm{b}} \quad$ 303A-B, B & B $\quad \begin{array}{l}\text { As in A, except alteration a darker green; pyroxene is possibly more } \\
\text { highly altered }\end{array}$
\end{tabular}

Site 304

$\begin{array}{lll}15-2,48-50 & 304-C, C & \text { C } \\ 16-2,130-132 & 304-D, D & \text { D }\end{array}$

Intergranular texture; olive-brown montmorillonite fills vesicles and occurs in patches in groundmass; plagioclase and pyroxene largely unaltered

Site 307

12-1, $145 \quad 307-\mathrm{E}, \mathrm{E}$

As in C, calcite fills some vesicles; montmorillonite is more yellow

13-1, 78-82 307F, F

E Only a vague suggestion of former igneous texture; rock is now composed of clear patches of montmorillonite, tiny red granules of goethite(?), and patches of a murky material (X-ray analy sis of a sample several $\mathrm{cm}$ removed shows the presence of K-feldspar, celadonite, chlorite, and montmorillonite)

F Pyroxene altered to montmorillonite, clouds of dark granular material have replaced and retain the form of the skeletal opaques, the plagioclase is also highly altered; X-ray analysis shows the sample to consist of a little plagioclase, much $\mathrm{K}$-feldspar, as well as celadonite and montmorillonite

$\begin{array}{ll}13-2,27-29 & 307-\mathrm{G}, \mathrm{G} \\ 13-2,80-82 & 307-\mathrm{H}, \mathrm{H} \quad \mathrm{H}\end{array}$

Intergranular texture of plagioclase laths and somewhat feathery pyroxene; plagioclase and pyroxene are mostly fresh, but green montmorillonite occurs as scattered patches (after pyroxene?) and filling vesicles; there are red-colored areas (goethite-stained montmorillonite?) where the alteration, especially of pyroxene is much more intense; occasional plagioclase phenocrysts

13-2, 80-82 $307-\mathrm{H}, \mathrm{H} \quad \mathrm{H}$

Plumose texture with scattered plagioclase microlites; patches of green montmorillonite between the fibrous plumes; finer grained than $\mathrm{G}$ and therefore probably closer to the crust, yet less altered

\section{Site 313}

$\begin{array}{lll}43-2,78-80 & 313-\mathrm{I}, \mathrm{I} & \\ 44-1,75-82 & 313-\mathrm{J}, \mathrm{J} & \mathrm{J} \\ & & \\ 44-2,125-127 & 313-\mathrm{K}, \mathrm{K} & \mathrm{K} \\ 44-3,144-146 & 313-\mathrm{L}, \mathrm{L} & \end{array}$

Plagioclase laths, titanaugite prisms, and fibrous, brown amphibole (hornblende?) in a matrix of palagonitized glass; vesicles filled with montmorillonite and calcite; cores of plagioclase laths frequently altered to phillipsite(?)

Intergranular texture of plagioclase laths, titanaugite prisms, elongate brown hornblende(?), and sparse, red-brown biotite; cores of plagioclase laths altered to phillipsite(?); vesicles filled with phillipsite; X-ray analysis shows presence of K-feldspar; amphibole appears to be primary

As above in J; scattered patches of dusty brown glass; except for alteration of plagioclase cores, rock appears fresh

L As above, except much more glass, which here is a darker, reddishbrown and palagonitized; X-ray analysis shows the presence of Kfeldspar

\footnotetext{
${ }^{\mathrm{a}}$ Analy sis code.

$\mathrm{b}_{\text {Figure code. }}$
} 
biotite, and possibly of primary amphibole in the basaltic units at Site 313 suggests it has alkalic affinities, but alteration precluded an estimate of modal nepheline content, if any was indeed present. All of the basaltic rocks examined are at least partially altered. The alteration appears to be most intense at the upper surface of basalt sections and near fractures. Many of the fractures at Sites 303 and 307 are bordered by zones $1-2 \mathrm{~cm}$ wide where the basalt is a darker green than the adjacent portions of the core. The glassy crusts alter largely to celadonite, whereas the silicate minerals usually alter to montmorillonite. Pyroxene usually has altered more readily than plagioclase. The basalt at Site 313 is an exception since the cores of the plagioclase laths are replaced with phillipsite, and it is far more altered than the pyroxene.

The most highly altered basaltic unit is that from Site 307 . The basalt immediately underlying the sediments is so severely altered that it is now brown to red claystone. Montmorillonite, celadonite, and chlorite totally replace the plagioclase and pyroxene grains, and the rocks retain only their intergranular texture and ghosts of the sparse, tiny, plagioclase glomerophenocrysts found deeper in the basalt. In a distance of less than a meter (measured in the recovered material and therefore a minimum value) the claystone becomes a somewhat hard, light greenish-gray "basalt" in which some of the opaques still remain but much of the plagioclase and pyroxene is now $\mathrm{K}$-feldspar, montmorillonite, and celadonite. At a distance of 2 meters below the top of the claystone, the basalt is dark gray and appears largely unaltered. However, as mentioned above, the glassy crusts of even these flows are altered to celadonite. The alteration is most intense near surfaces exposed to the sea water, or, possibly, hydrothermal solutions-surfaces such as flow margins (especially the topmost surface) and fractures. X-ray analysis of the white material cementing the hyaloclastite at this site shows it to be calcite and ankerite $\left[\mathrm{Ca}\left(\mathrm{Mg}, \mathrm{Fe}^{+2}, \mathrm{Mn}\right)\left(\mathrm{CO}_{3}\right)_{2}\right]$. The proportion of ankerite, relative to calcite, increases with time, so that the carbonate deposited in the later stages of cementation is almost entirely ankerite. The carbonate lining the vugs in the Site 313 basalt also becomes richer in ankerite with time. This progressive change from calcite to ankerite shows that at first only $\mathrm{Ca}$ is mobile, but with time other cations such as $\mathrm{Mg}$, $\mathrm{Fe}$, and $\mathrm{Mn}$ also become mobile. The overlying calcareous oozes probably provide some of the initial calcium, but weathering of the basalt obviously releases the other cations needed to form the void-filling carbonates.

\section{CHEMICAL COMPOSITION}

A chemical analysis was made of at least two basalt samples from each site. The major oxides were, for the most part, determined by X-ray fluorescence. $\mathrm{FeO}$ percent was determined by titration, $\mathrm{H}_{2} \mathrm{O}$ and $\mathrm{CO}_{2}$ were measured by the Penfield method and gasimetric analysis, respectively. $\mathrm{Na}_{2} \mathrm{O}$ and $\mathrm{K}_{2} \mathrm{O}$ percent were measured both by X-ray and flame photometry. The trace elements were determined by semiquantitative spectrographic analysis. The analyses were made in U.S. Geological Survey Laboratories in Menlo Park, California, and are given in Table 2 . Normative values are given in Table 3.
One sample from each site was taken from the leastaltered portion in order to classify the basalt chemically, whereas the other, more highly altered samples were analyzed to determine the chemical effects of sea-floor alteration. Specifically, the two samples from Hole 303A are contiguous, one (303A-B) is from the green basalt bordering a fracture, whereas the other (303A-A) is from gray, less highly altered basalt.

The two samples from 304 (304-C, 304-D) are an exception; both were taken from the freshest portions in the interior of the recovered basalt. The four analyses from Site 307 sample the full range of alteration found at this site. Sample 307-E is from the basalt-turned-toclaystone near the "basalt"-sediment contact, Sample $307-\mathrm{F}$ was taken about a meter lower in green, highly altered basalt, and Samples $307-\mathrm{G}$ and $307-\mathrm{H}$ were taken still deeper from the greenish-gray basalt in the interior of two pillows(?). Of the four samples from Site 313, two (313-J, 313-K) are from the relatively unaltered interior, whereas Samples 313-I and 313-L are from the more altered regions at the top and bottom, respectively, of the basaltic section. In the discussion and figures that follow, these samples and their chemistry will be referenced by the letter following the hole number. A schematic indication of the degree of alteration of each sample is given in Table 1.

The pervasive alteration observed in these old basalts is most obvious in their high $\mathrm{H}_{2} \mathrm{O}$ content $(1 \%-13 \%)$, high $\mathrm{Fe}_{2} \mathrm{O}_{3} / \mathrm{FeO}$ ratios (0.4-10) and, in the Site 307 basalts, their $\mathrm{CO}_{2}$ content $(0.5 \%-3 \%)$. Basalts currently forming at ocean ridges typically have less than $1 \% \mathrm{H}_{2} \mathrm{O}$ and $\mathrm{Fe}_{2} \mathrm{O}_{3} / \mathrm{FeO}$ ratios of 0.2 (Miyashiro et al., 1969). In order to restore the chemistry of the basalts approximately to their initial composition, the $\mathrm{H}_{2} \mathrm{O}$ and $\mathrm{CO}_{2}$ were removed, all the iron was computed as $\mathrm{FeO}$, and the analyses were normalized (Table 2), and dry normalized norms were computed (Table 3).

With the notable exception of the Site 313 basalt, the least-altered basalts from each site (A, C, D, and H) plot in the tholeiitic field on Macdonald's (1968) total alkalisilica diagram (Figure 1). Site 313 basalt plots well in the alkalic field, agreeing with the mineralogic indications of its alkalic nature, i.e., the presence of titanaugite, biotite, even primary (?) amphibole. Although modal nepheline was not positively identified, Site 313 basalt is nepheline normative, whereas quartz appears in the norms calculated from the uncorrected analyses of the other basalts (Table 3 ).

The percent of $\mathrm{K}_{2} \mathrm{O}$ increases dramatically with alteration, which, along with an initial decrease in $\mathrm{SiO}_{2}$, causes the position of fresher tholeiitic basalts such as Samples A and $\mathrm{H}$ to shift toward the alkalic field (Samples B and G, respectively). Compositions from uncorrected or only partially corrected analyses (Samples G" and $\mathrm{G}^{\prime}$, respectively) plot in the alkali basalt field (Figure 1). Although $\mathrm{SiO}_{2}$ begins to increase with further alteration, the continued increase in $\mathrm{K}_{2} \mathrm{O}$ makes the highly altered basalt $(F)$ plot in the alkalic field. In the extreme, alteration of the basalt to claystone decreases the $\mathrm{K}_{2} \mathrm{O}$ and $\mathrm{SiO}_{2}$ in such a way that the rock (Sample E) can be chemically classified as a tholeiitic claystone!

Trace element contents (Figures 2 and 3) separate the basalts into two groups even more clearly. The low $\mathrm{Sr}$, $\mathrm{Zr}$, and $\mathrm{Nb}$ values place the basalts from Sites 303,304 , 
TABLE 2

Chemistry of Volcanic Rocks, DSDP Leg 32

\begin{tabular}{|c|c|c|c|c|c|c|c|c|c|c|c|c|}
\hline & $303 \mathrm{~A}-\mathrm{A}^{\mathrm{a}}$ & $303 \mathrm{~A}-\mathrm{A}^{\mathrm{b}}$ & $303 \mathrm{~A}-\mathrm{B}^{\mathrm{a}}$ & $303 \mathrm{~A}-\mathrm{B}^{\mathrm{b}}$ & $304-C^{a}$ & $304-C^{b}$ & $304-D^{a}$ & $304-\mathrm{D}^{\mathrm{b}}$ & $307-E^{a}$ & $307-E^{b}$ & $307-\mathrm{F}^{\mathrm{a}}$ & $307-\mathrm{F}^{\mathrm{b}}$ \\
\hline $\mathrm{SiO}_{2}$ & 49.05 & 51.35 & 47.93 & 50.66 & 49.56 & 50.65 & 49.08 & 50.65 & 48.69 & 56.48 & 50.87 & 57.28 \\
\hline $\mathrm{Al}_{2} \mathrm{O}_{3}$ & 14.43 & 15.11 & 13.52 & 14.29 & 13.05 & 13.33 & 12.80 & 13.21 & 17.34 & 20.11 & 16.68 & 18.78 \\
\hline $\mathrm{Fe}_{2} \mathrm{O}_{3}$ & 3.53 & & 7.35 & & 3.86 & & 4.15 & & 10.44 & & 7.61 & \\
\hline $\mathrm{FeO}$ & 5.51 & 9.10 & 5.05 & 12.32 & 9.21 & 12.96 & 8.98 & 13.12 & 0.40 & 11.36 & 0.83 & 8.65 \\
\hline $\mathrm{MgO}$ & 6.10 & 6.39 & 4.88 & 5.15 & 6.57 & 6.71 & 6.27 & 6.47 & 2.38 & 2.76 & 2.34 & 2.63 \\
\hline $\mathrm{CaO}$ & 10.11 & 10.59 & 9.03 & 9.55 & 10.60 & 10.83 & 10.93 & 11.28 & 0.59 & 0.68 & 1.83 & 2.06 \\
\hline $\mathrm{Na}_{2} \mathrm{O}$ & 3.08 & 3.22 & 2.81 & 2.97 & 2.78 & 2.84 & 2.53 & 2.61 & 1.29 & 1.49 & 1.56 & 1.76 \\
\hline $\mathrm{K}_{2} \mathrm{O}$ & 0.38 & 0.40 & 1.32 & 1.46 & 0.08 & 0.08 & 0.09 & 0.09 & 3.98 & 4.62 & 5.84 & 6.57 \\
\hline $\mathrm{H}_{2} \mathrm{O}^{+}$ & 0.79 & & 0.38 & & 0.23 & & 0.12 & & 4.47 & & 3.25 & \\
\hline $\mathrm{H}_{2} \mathrm{O}^{-}$ & 3.07 & & 2.62 & & 1.40 & & 1.18 & & 8.45 & & 6.23 & \\
\hline $\mathrm{TiO}_{2}$ & 3.12 & 3.26 & 2.98 & 3.15 & 2.07 & 2.11 & 2.08 & 2.15 & 1.90 & 2.20 & 1.76 & 1.99 \\
\hline $\mathrm{P}_{2} \mathrm{O}_{5}$ & 0.32 & 0.33 & 0.31 & 0.33 & 0.22 & 0.22 & 0.20 & 0.21 & 0.24 & 0.28 & 0.18 & 0.20 \\
\hline $\mathrm{MnO}$ & 0.18 & 0.19 & 0.20 & 0.21 & 0.22 & 0.22 & 0.22 & 0.23 & 0.02 & 0.02 & 0.04 & 0.04 \\
\hline $\mathrm{CO}_{2}$ & 0.10 & & 0.05 & & 0.13 & & 0.63 & & 0.06 & & 1.02 & \\
\hline Total & 99.77 & 99.94 & 98.43 & 100.09 & 99.98 & 99.95 & 99.26 & 100.02 & 100.25 & 100.00 & 99.95 & 99.96 \\
\hline
\end{tabular}

PPM:

B 7

$\mathrm{Ba} \quad 10$

30

Co 50

10

30

70

70

15
50

50

70

70

$\mathrm{Cu} \quad 70$

$\mathrm{La}$

$\mathrm{Nb}$

$\mathrm{Ni} \quad 70$

50

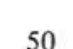

50
50

50
70

70

70
200

300

200

70

50

150

100

15
50
70
70

$\begin{array}{rr}70 & 100 \\ 20 & 200 \\ 20 & 30 \\ 150 & 150 \\ 50 & 100\end{array}$

${ }^{\mathrm{a}}$ Analysis as received.

${ }^{b}$ Analysis dry, reduced, and normalized. Analysts: Major elements - H. N. Elsheimer, J. F. Espos, and B. P. Fabbi; $\mathrm{FeO}, \mathrm{H}_{2} \mathrm{O}^{+}$, $\mathrm{H}_{2} \mathrm{O}^{-}, \mathrm{CO}_{2}-$ S. T. Neil, $\mathrm{Na}_{2} \mathrm{O}, \mathrm{K}_{2} \mathrm{O}-$ L. Schlocker; minor elements $-\mathrm{H}$. Bastron, all of the U. S. Geological Survey.

and 307 well inside the ocean ridge basalt field (Bass et al., 1973), whereas the distinctly higher values classify the Site 313 basalt as alkalic. None of the rocks fall in the Bass et al. "oceanic island tholeiite" field.

The variation in basalt chemistry with increasing alteration is best seen in the four samples from Site 307. The percent of $\mathrm{SiO}_{2}, \mathrm{Al}_{2} \mathrm{O}_{3}$, and $\mathrm{K}_{2} \mathrm{O}$ all increase, whereas $\mathrm{CaO}, \mathrm{Na}_{2} \mathrm{O}, \mathrm{MgO}$, and $\mathrm{MnO}$ decrease, and $\mathrm{TiO}_{2}$ remains fairly constant (Figure 4). The effect of alteration on $\mathrm{P}_{2} \mathrm{O}_{5}$ appeared to fluctuate, although Bass et al. (1973) contend that $\mathrm{P}_{2} \mathrm{O}_{5}$ and $\mathrm{TiO}_{2}$ are stable minor elements whose ratios are diagnostic of original chemical compositions of altered basalts. Total iron ( $\mathrm{FeO} *$ ) percentage fluctuates, but the iron is increasingly oxidized to $\mathrm{Fe}_{2} \mathrm{O}_{3}$. The amount of $\mathrm{H}_{2} \mathrm{O}$, contained largely in the montmorillonite and celadonite, likewise increases sharply. The changes in oxide percent are relative except for the obvious addition of $\mathrm{H}_{2} \mathrm{O}$ to the basalt. Whether the $\mathrm{SiO}_{2}$ and $\mathrm{Al}_{2} \mathrm{O}_{3}$ percent increase is due to the actual loss of $\mathrm{CaO}, \mathrm{MgO}$, and $\mathrm{MnO}$ or to the addition of $\mathrm{SiO}_{2}$ and $\mathrm{Al}_{2} \mathrm{O}_{3}$ is ambiguous. However, carbonates commonly fill fractures, cement breccia and line 
TABLE 2 - Continued

\begin{tabular}{|c|c|c|c|c|c|c|c|c|c|c|c|c|}
\hline & $307-G^{a}$ & $307-\mathrm{G}^{\mathrm{b}}$ & $307-\mathrm{H}^{\mathrm{a}}$ & $307-\mathrm{H}^{\mathrm{b}}$ & $313-\mathrm{I}^{\mathrm{a}}$ & $313-\mathrm{I}^{\mathrm{b}}$ & $313-\mathrm{J}^{\mathrm{a}}$ & $313-\mathrm{J}^{\mathrm{b}}$ & $313-\mathrm{K}^{\mathrm{a}}$ & $313-\mathrm{K}^{\mathrm{b}}$ & $313-\mathrm{L}^{\mathrm{a}}$ & $313-\mathrm{L}^{\mathrm{b}}$ \\
\hline $\mathrm{SiO}_{2}$ & 45.56 & 50.02 & 49.00 & 52.04 & 45.27 & 49.66 & 50.99 & 52.62 & 47.87 & 50.88 & 51.47 & 52.96 \\
\hline $\mathrm{Al}_{2} \mathrm{O}_{3}$ & 14.08 & 15.46 & 14.82 & 15.74 & 17.52 & 19.22 & 16.20 & 16.72 & 16.72 & 17.77 & 15.94 & 16.40 \\
\hline $\mathrm{Fe}_{2} \mathrm{O}_{3}$ & 5.60 & & 4.50 & & 6.66 & & 5.35 & & 5.08 & & 5.33 & \\
\hline $\mathrm{FeO}$ & 4.67 & 10.66 & 5.13 & 9.75 & 2.71 & 9.54 & 3.16 & 8.23 & 3.25 & 8.31 & 2.99 & 8.01 \\
\hline $\mathrm{MgO}$ & 5.48 & 6.02 & 5.33 & 5.66 & 3.00 & 3.29 & 3.07 & 3.17 & 3.12 & 3.32 & 2.88 & 2.96 \\
\hline $\mathrm{CaO}$ & 10.84 & 11.90 & 10.70 & 11.36 & 6.21 & 6.81 & 6.77 & 6.99 & 6.49 & 6.90 & 6.06 & 6.23 \\
\hline $\mathrm{Na}_{2} \mathrm{O}$ & 2.60 & 2.85 & 2.68 & 2.85 & 4.13 & 4.53 & 4.08 & 4.21 & 4.49 & 4.77 & 3.61 & 3.71 \\
\hline $\mathrm{K}_{2} \mathrm{O}$ & 0.81 & 0.89 & 0.58 & 0.62 & 2.41 & 2.64 & 4.34 & 4.48 & 4.18 & 4.44 & 6.05 & 6.22 \\
\hline $\mathrm{H}_{2} \mathrm{O}^{+}$ & 1.22 & & 0.84 & & 3.41 & & 1.10 & & 3.18 & & 1.08 & \\
\hline $\mathrm{H}_{2} \mathrm{O}^{-}$ & 2.71 & & 2.35 & & 3.80 & & 1.47 & & 2.33 & & 0.77 & \\
\hline $\mathrm{TiO}_{2}$ & 1.46 & 1.60 & 1.56 & 1.66 & 2.56 & 2.80 & 2.35 & 2.42 & 2.38 & 2.53 & 2.30 & 2.36 \\
\hline $\mathrm{P}_{2} \mathrm{O}_{5}$ & 0.35 & 0.38 & 0.17 & 0.18 & 1.14 & 1.25 & 0.88 & 0.91 & 0.83 & 0.88 & 0.88 & 0.90 \\
\hline $\mathrm{MnO}$ & 0.15 & 0.16 & 0.15 & 0.16 & 0.18 & 0.20 & 0.18 & 0.19 & 0.18 & 0.19 & 0.18 & 0.19 \\
\hline $\mathrm{CO}_{2}$ & 3.34 & & 2.05 & & 0.54 & & 0.05 & & 0.20 & & 0.05 & \\
\hline Total & 98.87 & 99.94 & 99.86 & 100.02 & 99.54 & 99.94 & 99.99 & 99.94 & 100.30 & 100.00 & 99.63 & 99.94 \\
\hline
\end{tabular}

PPM:

\begin{tabular}{|c|c|c|c|c|c|c|}
\hline B & & & 50 & 10 & 10 & 10 \\
\hline $\mathrm{Ba}$ & 7 & 10 & 200 & 200 & 200 & 200 \\
\hline Co & 50 & 30 & 10 & 10 & 10 & 10 \\
\hline $\mathrm{Cr}$ & 200 & 150 & & & & \\
\hline $\mathrm{Cu}$ & 50 & 70 & 7 & 7 & 7 & 7 \\
\hline $\mathrm{La}$ & & & 100 & 100 & 100 & 100 \\
\hline $\mathrm{Nb}$ & & & 50 & 50 & 50 & 50 \\
\hline $\mathrm{Ni}$ & 50 & 50 & & & & \\
\hline $\mathrm{Sc}$ & 50 & 50 & 5 & 5 & 5 & 5 \\
\hline $\mathrm{Sr}$ & 100 & 70 & 700 & 700 & 500 & 500 \\
\hline V & 200 & 200 & 70 & 70 & 70 & 100 \\
\hline Y & 50 & 30 & 50 & 30 & 50 & 30 \\
\hline $\mathrm{Zr}$ & 50 & 50 & 300 & 300 & 300 & $\cdot 300$ \\
\hline
\end{tabular}

vugs in these basalts. As mentioned above, the carbonate which cements the breccia at Site 307 and lines the vugs in the Site 313 basalt becomes increasingly calcite poor and ankerite rich with time. Although the needed cations could have come from the overlying sediments or the seawater itself, the decrease in $\mathrm{CaO}, \mathrm{MgO}$, and $\mathrm{MnO}$ observed in the basalt may well represent a real loss of these elements to form the void-filling carbonates.

Like the major elements, the trace elements vary differently with increasing alteration (Figure 5). Ni increases, $\mathrm{Sr}$ decreases, both $\mathrm{Ba}$ and $\mathrm{V}$ increase initially and then decrease, whereas $\mathrm{Cu}$ fluctuates with increasing alteration. The amount of $\mathrm{Co}, \mathrm{Cr}, \mathrm{Sc}, \mathrm{Y}$, and especially $\mathrm{Zr}$ remains fairly constant. The most dramatic change is the large increase in boron, which is absorbed along with the seawater.

\section{CONCLUSIONS}

Although the basaltic rocks cored on Leg 32 were rather extensively altered, it is possible to say with some assurance that those recovered from Sites 303, 304, and 307 , all at locations presumed to be Mesozoic ocean floor, were oceanic tholeiites, not markedly different from those now being extruded at mid-oceanic ridges. The basaltic rocks cored at Site 313, in the Mid-Pacific Mountains, on the other hand, contain primary titanaugite, biotite, and possibly amphibole, and its composition is definitely alkalic, and possibly basanitic or nephelenitic. The alkalic composition suggests that the basalt is neither part of the ridge-generated oceanic crust nor part of the early archipelagic apron, but instead formed somewhat late in the development of the nearby seamounts. 
TABLE 3

Molecular Norms of Volcanic Rocks, DSDP Leg 32

\begin{tabular}{|c|c|c|c|c|c|c|c|c|c|c|c|c|}
\hline & $303 \mathrm{~A}-\mathrm{A}^{\mathrm{a}}$ & $303 \mathrm{~A}-\mathrm{A}^{\mathrm{b}}$ & $303 \mathrm{~A}-\mathrm{B}^{\mathrm{a}}$ & $303 \mathrm{~A}-\mathrm{B}^{\mathrm{b}}$ & $304-C^{a}$ & $304-C^{b}$ & $304-D^{a}$ & $304-D^{b}$ & $307-\mathrm{E}^{\mathrm{a}}$ & $307-\mathrm{E}^{\mathrm{b}}$ & $307-\mathrm{F}^{\mathrm{a}}$ & $307-\mathrm{F}^{\mathrm{b}}$ \\
\hline Q & 4.13 & & 5.91 & & 2.62 & & 4.57 & & 23.99 & 17.47 & 16.33 & 8.36 \\
\hline C & & & & & & & & & 11.51 & 12.09 & 7.72 & 5.51 \\
\hline $\mathrm{Z}$ & 0.03 & & 0.03 & & 0.01 & & 0.01 & & 0.01 & & 0.01 & \\
\hline OR & 2.30 & 2.37 & 8.14 & 8.63 & 0.47 & 0.47 & 0.53 & 0.53 & 25.59 & 27.28 & 36.80 & 38.84 \\
\hline $\mathrm{AB}$ & 26.90 & 27.29 & 24.76 & 25.13 & 23.87 & 24.06 & 21.84 & 22.09 & 11.85 & 12.63 & 14.04 & 14.90 \\
\hline AN & 25.28 & 25.58 & 21.21 & 21.32 & 23.21 & 23.39 & 23.74 & 24.07 & 1.03 & 1.55 & 1.58 & 8.92 \\
\hline \multicolumn{13}{|l|}{$\mathrm{NE}$} \\
\hline WO & 9.92 & 10.37 & 9.60 & 9.96 & 11.64 & 12.07 & 10.93 & 12.75 & & & & \\
\hline EN & 15.71 & 15.58 & 12.66 & 8.93 & 16.59 & 13.32 & 15.92 & 14.35 & 6.45 & 6.88 & 6.20 & 6.55 \\
\hline FS & 2.48 & 11.43 & & 12.40 & 10.87 & 16.50 & 10.23 & 18.79 & & 17.26 & & 12.68 \\
\hline FO & & 0.24 & & 2.73 & & 2.39 & & 1.17 & & & & \\
\hline FA & & 0.19 & & 4.17 & & 3.27 & & 1.69 & & & & \\
\hline MT & 5.29 & & 8.66 & & 5.67 & & 6.14 & & & & & \\
\hline $\mathrm{CM}$ & 0.01 & & 0.01 & & 0.01 & & 0.01 & & 0.03 & & 0.03 & \\
\hline $\mathrm{HM}$ & & & 1.87 & & & & & & 11.37 & & 8.11 & \\
\hline IL & 6.13 & 6.20 & 5.90 & 5.98 & 3.99 & 4.01 & 4.03 & 4.08 & 0.97 & 4.18 & 1.94 & 3.78 \\
\hline RV & & & & & & & & & 1.56 & & 0.86 & \\
\hline AP & 0.78 & 0.78 & 0.76 & 0.78 & 0.52 & 0.52 & 0.47 & 0.50 & 0.62 & 0.66 & 0.45 & 0.47 \\
\hline $\mathrm{CC}$ & 0.23 & & 0.11 & & 0.30 & & 1.46 & & 0.16 & & 2.48 & \\
\hline
\end{tabular}

Variation in chemical composition in progressively increasingly altered rocks includes increases in $\mathrm{H}_{2} \mathrm{O}, \mathrm{CO}_{2}$, $\mathrm{S}_{1} \mathrm{O}_{2}, \mathrm{Al}_{2} \mathrm{O}_{3}, \mathrm{~K}_{2} \mathrm{O}, \mathrm{Ni}$, and $\mathrm{B}$, and decreases in $\mathrm{CaO}$, $\mathrm{Na}_{2} \mathrm{O}, \mathrm{MgO}, \mathrm{MnO}$, and $\mathrm{Sr}$. Total iron, $\mathrm{P}_{2} \mathrm{O}_{5}, \mathrm{Ba}, \mathrm{V}$, and $\mathrm{Cu}$ fluctuate, but the oxidation ratio of iron increases with increasing alteration. $\mathrm{TiO}_{2}, \mathrm{Co}, \mathrm{Cr}, \mathrm{Sc}$, and particularly $\mathrm{Zr}$, remain fairly constant during alteration and should be continued to be examined as indicators of original compositional fields of altered basalts.

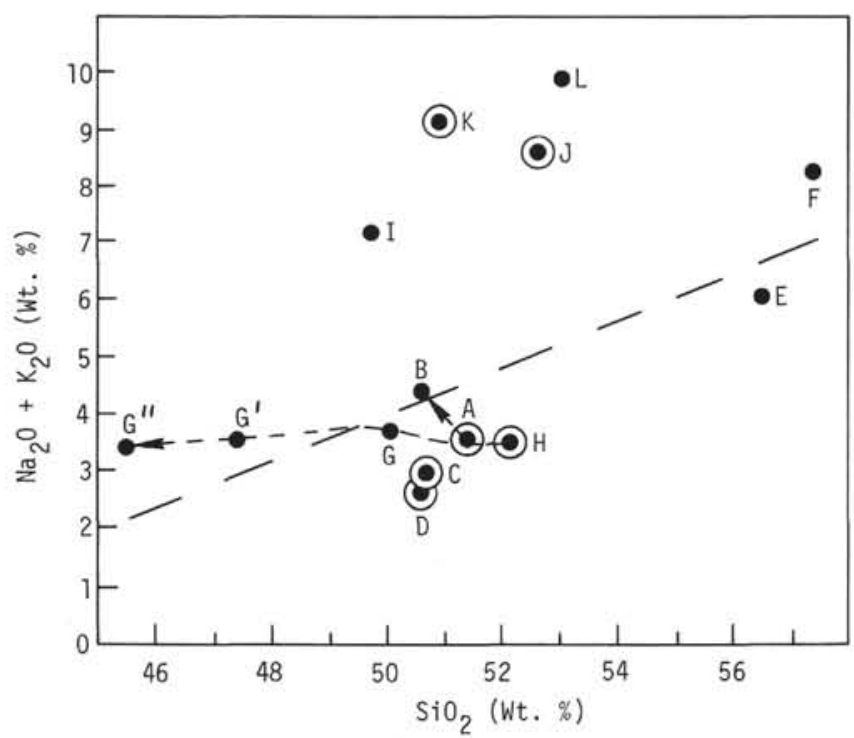

Figure 1. Alkali-silica diagram with the boundary (dashed line) between the tholeiitic and alkalic fields as deter- mined for Hawaiian basalts (Macdonald, 1968). Samples are referenced by the final letter in the sample code in Table 2, The oxide percentages for sample G" are from the analysis as received, those for sample $G$ ' are from the analysis less $\mathrm{H}_{2} \mathrm{O}^{-}$and normalized, and those for all the other samples are from the dry, reduced, and nornalized analyses (see Table 2). The fresher samples from each site are circled. Arrows indicate changes with increasing alteration at two sites.

\section{ACKNOWLEDGMENTS}

The author thanks Keith Bargar for his X-ray determination of the basalt alteration products and void-filling materials and Dale Jackson for his helpful revision of this paper. Both Bargar and Jackson are with the U.S. Geological Survey at Menlo Park, California.

\section{REFERENCES}

Bass, M. N., Moberly, R., Rhodes, J. M., Shih, C.-Y., and Church, S. E., 1973. Volcanic rocks cored in the central Pacific, Leg 17. In Winterer, E. L., Ewing, J. I., et al., Initial Reports of the Deep Sea Drilling Project, Volume 17: Washington (U.S. Government Printing Office), p. 429503.

Macdonald, G. A., 1968. Composition and origin of Hawaiian lavas. In Coats, R. R., Hay, R. L., and Anderson, C.A., Studies in volcanology, Geol. Soc. Am. Mem. 116, 477-522.

Macdonald, G. A. and Katsura, T., 1964. Chemical composition of Hawaiian lavas: J. Petrol., v. 5, p. 82-133.

Miyashiro, A., Shido, F., and Ewing, M., 1969. Diversity and origin of abyssal tholeiite from the mid-Atlantic Ridge near $24^{\circ}$ and $30^{\circ}$ north latitude: Contrib. Min. Petrol., v. 23, p. $38-52$. 
TABLE 3-Continued

\begin{tabular}{|c|c|c|c|c|c|c|c|c|c|c|c|}
\hline $307-G^{\mathrm{a}}$ & $307-G^{b}$ & $307-\mathrm{H}^{\mathrm{a}}$ & $307-\mathrm{H}^{\mathrm{b}}$ & $313-I^{\mathrm{a}}$ & $313-I^{b}$ & $313-\mathrm{J}^{\mathrm{a}}$ & $313-J^{b}$ & $313-K^{a}$ & $313-K^{b}$ & $313-\mathrm{L}^{\mathrm{a}}$ & $313-L^{b}$ \\
\hline \multirow[t]{2}{*}{6.80} & & 7.69 & & & & & & & & & \\
\hline & & & & 0.82 & & & & & & & \\
\hline 0.01 & & 0.01 & & 0.06 & & 0.06 & & 0.06 & & 0.06 & \\
\hline 4.97 & 5.26 & 3.49 & 3.66 & 14.89 & 15.61 & 26.02 & 26.49 & 25.18 & 26.24 & 36.17 & 36.80 \\
\hline 22.86 & 24.13 & 23.27 & 24.11 & 36.47 & 31.39 & 30.60 & 25.27 & 24.82 & 19.28 & 22.80 & 17.50 \\
\hline \multirow[t]{2}{*}{25.33} & 26.78 & 27.37 & 28.32 & 20.87 & 24.33 & 13.26 & 13.50 & 13.39 & 13.97 & 9.53 & 9.71 \\
\hline & & & & & 3.77 & 2.41 & 5.62 & 7.55 & 11.42 & 4.38 & 7.55 \\
\hline 2.61 & 12.45 & 5.29 & 11.21 & & 0.54 & 6.13 & 6.37 & 5.30 & 6.06 & 6.18 & 6.41 \\
\hline 14.18 & 6.48 & 13.60 & 13.32 & 3.94 & 0.21 & 5.30 & 2.61 & 4.58 & 2.55 & 5.34 & 2.57 \\
\hline \multirow[t]{3}{*}{1.88} & 7.45 & 3.49 & 14.61 & & 0.34 & & 3.80 & & 3.54 & & 3.90 \\
\hline & 5.97 & & 0.54 & 2.70 & 5.60 & 1.71 & 3.70 & 2.34 & 3.99 & 1.34 & 3.37 \\
\hline & 7.56 & & 0.65 & & 10.00 & & 5.93 & & 6.10 & & 5.62 \\
\hline 8.44 & & 6.69 & & 2.00 & & 4.01 & & 4.25 & & 3.57 & \\
\hline \multirow[t]{2}{*}{0.04} & & 0.03 & & & & & & & & & \\
\hline & & & & 5.57 & & 2.66 & & 2.25 & & 2.93 & \\
\hline 2.89 & 3.04 & 3.04 & 3.15 & 5.07 & 5.32 & 4.52 & 4.60 & 4.62 & 4.81 & 4.42 & 4.49 \\
\hline 0.85 & 0.90 & 0.40 & 0.43 & 2.82 & 2.96 & 2.11 & 2.16 & 2.01 & 2.08 & 2.11 & 2.13 \\
\hline 7.89 & & 4.78 & & 1.27 & & 0.11 & & 0.45 & & 0.11 & \\
\hline
\end{tabular}

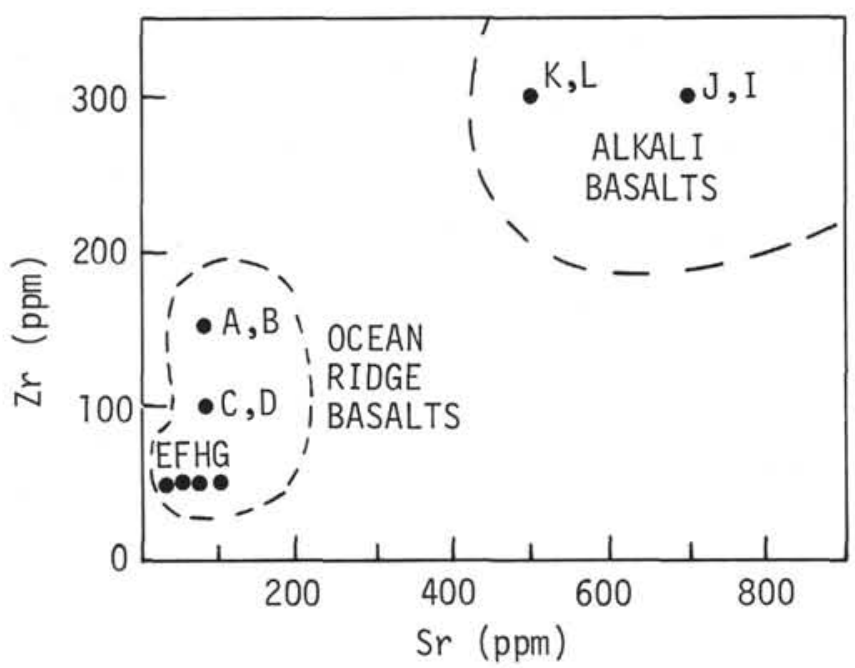

Figure 2. Trace element plots with fields for ocean ridge and alkali basalts from Bass et al. (1973).

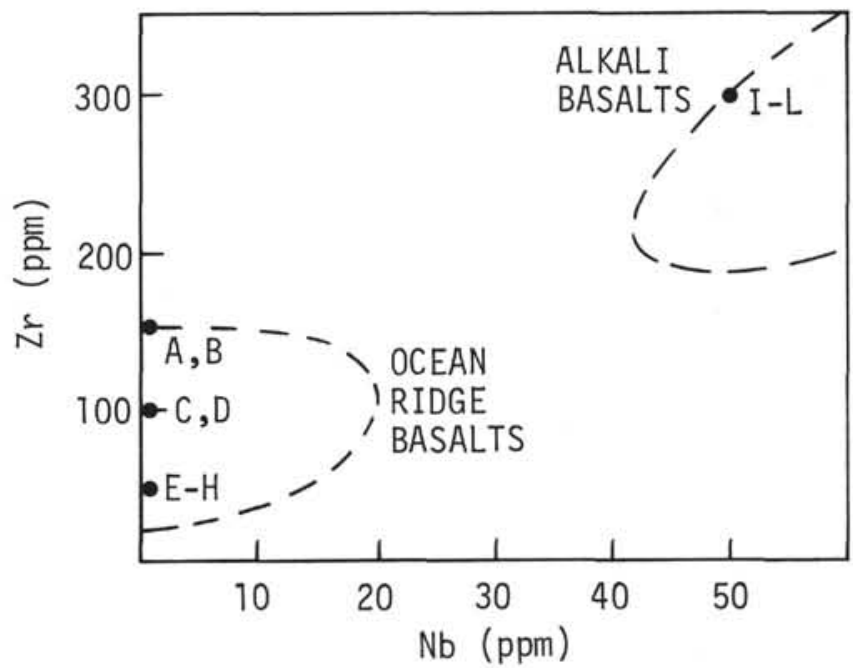

Figure 3. Trace element plots with fields for ocean ridge and alkali basalts from Bass et al. (1973). 


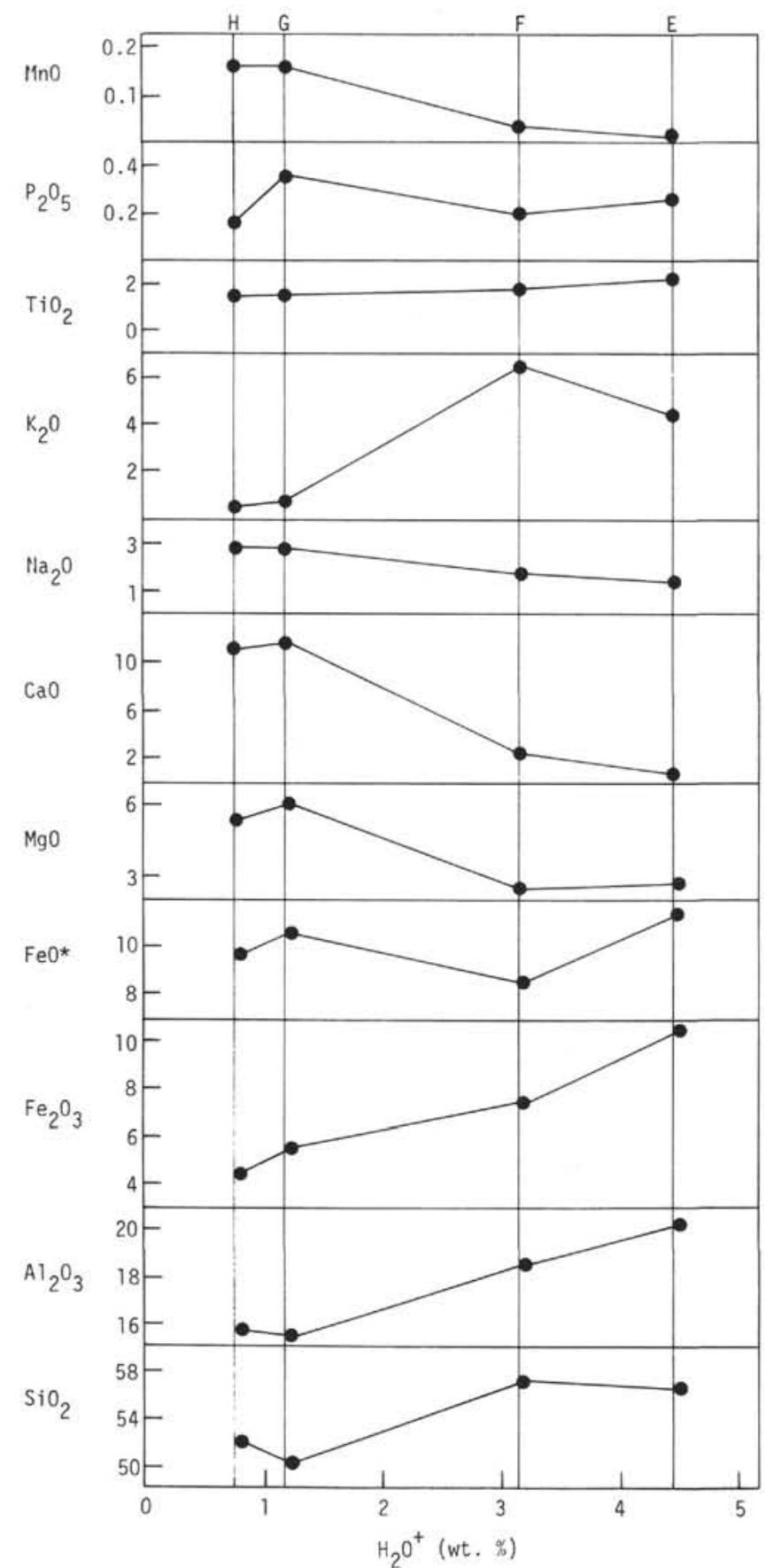

Figure 4. Variation of major oxide percentages with basalt alteration at Site 307. The $\mathrm{H}_{2} \mathrm{O}^{+}$contents is used as a semiquantitative estimate of the degree of alteration. The oxide percentages are from the dry, reduced and normalized analysis (Table 2).

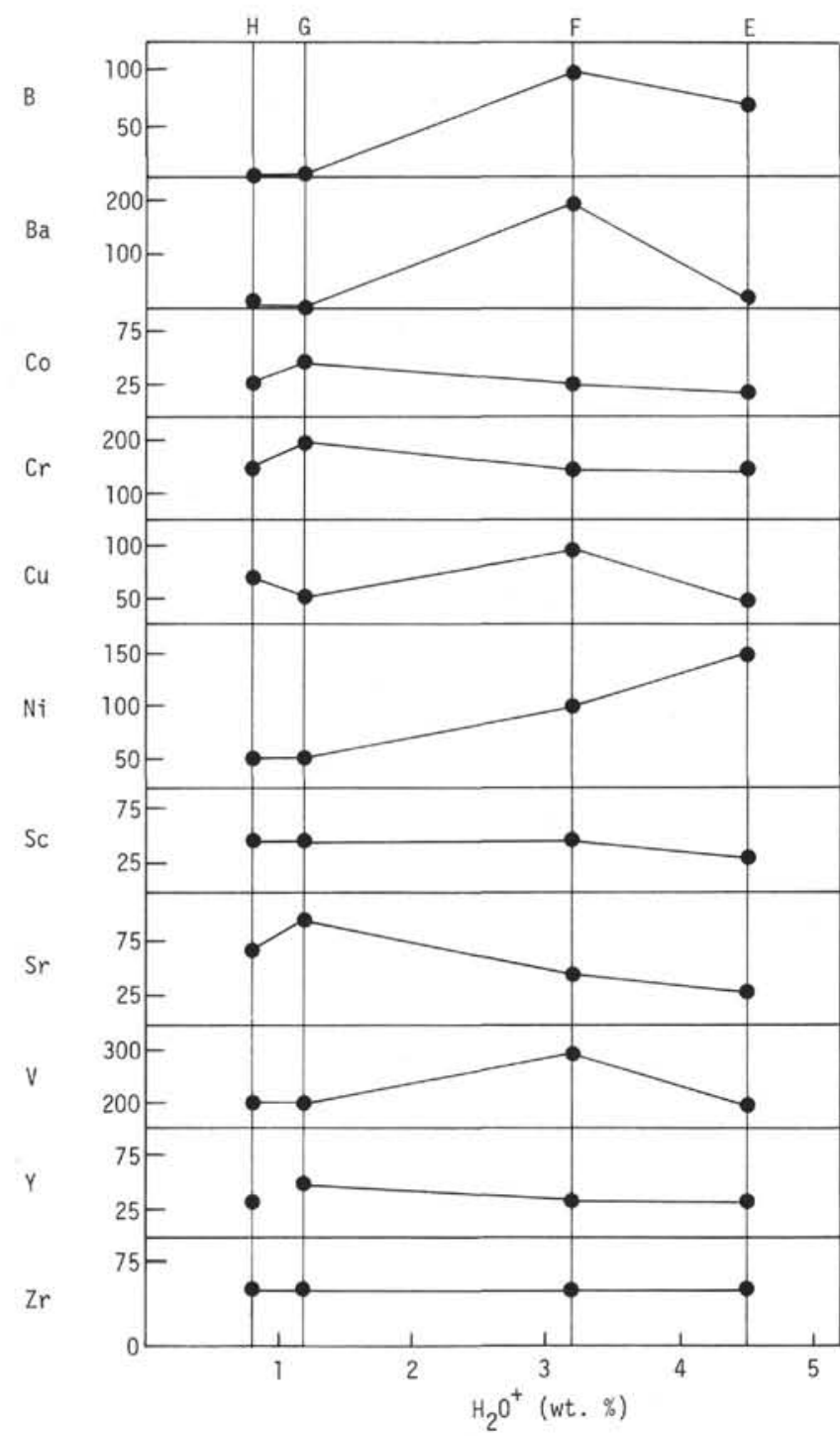

Figure 5. Variation of trace element content (PPM) with degree of alteration of Site 307 basalt. Data from Table 2. 